Wojciech Dobosz ${ }^{1}$

\title{
Rozum jako naturalna droga do wiary - zapomniana koncepcja Teodoreta z Cyru
}

Jednym z największych problemów dzisiejszego świata, na który wskazywał już Jan Paweł II w swojej encyklice Fides et ratio, jest kryzys poczucia sensu rozwijający się w konsekwencji odrzucenia przez współczesne modernistyczne nurty filozoficzne możliwości dojścia do prawdy samej w sobie, a co istotniejsze odrzucenie potrzeby poszukiwania prawdy istnienia $^{2}$. W tym kontekście niezmiernie ważna jest chrześcijańska perspektywa, która od zawsze wskazywała na niezbędność współdziałania wiary i rozumu prowadzących do komplementarnego rozwoju człowieka i pozwalających w pełni zrozumieć jego miejsce w świecie. Wiara i rozum zabezpieczają się wzajemnie i otwierają przed sobą nowe perspektywy. Wiara otwiera rozum człowieka na pytanie o sens istnienia, o istotę bytu, a rozum pozwala przybliżyć prawdy wiary i uczynić je zrozumiałymi. Stąd niezmiernie ważne jest współdziałanie wszystkich wyznań chrześcijańskich, by wyrwać świat z zacieśniającego i prowadzącego do błędnego przekonania, że rozum powinien w ogóle wykluczyć perspektywę wiary, a przyjąć tylko te dane, które są naukowo sprawdzalne. Tak rozumiane działanie mogłoby stać się kolejnym krokiem ekumenicznego zbliżenia, gdyż nie tylko ukazywałoby chrześcijaństwo jako prawdziwą filozofię, odkrywającą przed człowiekiem sens jego istnienia, ale także uświadamiałoby chrześcijanom wspólne fundamenty wiary i wspólny cel, do którego zostali powołani - głoszenie zbawienia człowieka w Jezusie Chrystusie. Niezmiernie ważne staje się więc dobranie odpowiedniej metody porozumiewania się ze światem współczesnym, która ukazałaby chrześcijaństwo jako w pełni racjonalną, prawdziwą filozofię. Papież Jan Paweł II wskazuje, że niezbędne w tym poszukiwaniu jest odkrycie na nowo dorobku Ojców

1 Wojciech Dobosz, doktorant Wydziału Teologicznego na Uniwersytecie Opolskim, e-mail: wojpiotrdob@gmail.com, ORCID: 0000-0003-1951-7272.

2 Jan Paweł II, Fides et ratio 80-91, 104, Watykan 1998. 
Kościoła ${ }^{3}$, którzy, działając w ramach niepodzielonego jeszcze Kościoła, mierząc się z filozofią grecką i wykształconymi warstwami cesarstwa, potrafili wypracować gotową metodę uzasadnienia chrześcijaństwa jako jedynej, sięgającej głębi bytu odpowiedzi na pytanie o sens istnienia i prawdę o świecie. Jednym z wybitnych przedstawicieli tego nurtu tradycji jest Teodoret z Cyru, którego apologetyczna metoda może stać się wzorem dialogu ze współczesnością.

Teodoret z Cyru jednak to w środowisku polskim dość zapomniana postać. Tłumaczenia jego tekstów na język polski ograniczają się tylko do kilku dzieł egzegetycznych i apologetycznych, Listów oraz Dziejów Bożej Miłoścí. W literaturze obcojęzycznej natomiast przekładu i krytycznego opracowania doczekały się w większości wszystkie jego dzieła ${ }^{5}$. Okoliczności te doprowadziły do sytuacji, w której brakuje także pogłębionej refleksji nad myśla tego syryjskiego Ojca Kościoła, a zwłaszcza nad jego sposobem dotarcia do klasycznie wykształconego przedstawiciela myśli greckiej, dla którego chrześcijaństwo nie było niczym innym jak bajką, którą opowiadają niewykształceni rybacy ${ }^{6}$. Teodoret przyjmuje więc sobie za cel przedstawienie i uzasadnienie wiary w Chrystusa jako ideału filozofii, swoistego punktu kulminacyjnego wszystkich dążeń tych, którzy umiłowali mądrość. W tym artykule skupię się przede wszystkim na jego najwcześniejszym dziele Leczenie chorób hellenizmu ${ }^{7}$, w którym przedstawił ramy swojej oryginalnej metody przekonywania do wiary w Chrystusa, a którą w późniejszych swoich dziełach, w ramach dojrzewania teologicznego i duszpasterskiego rozwijał i udoskonalał. Niemożliwe jest w ramach

3 Jan Paweł II, Fides et ratio 37-41, Watykan 1998.

$4 \quad$ Teodoret biskup Cyru, Dzieje miłości Bożej. Historia mnichów syryjskich, tł. K. Augustyniak, ŹM 7, Kraków 1994; Teodoret z Cyru, Komentarz do Listów Św. Pawła do Rzymian, tł. S. Kalinkowski, ŹMT 5, Kraków 1997; Teodoret z Cyru, Komentarz do 1 i 2 Listu do Koryntian, tł. S. Kalinkowski, ŹMT 9, Kraków 1998; Teodoret z Cyru, Komentarz do Listów Św. Pawła do: Galatów, Efezjan, Filipian, Kolosan, tł. S. Kalinkowski, ŹMT 14, Kraków 1999; Teodoret z Cyru, Komentarz do Listów Pawłowych do Tesaloniczan, Tymoteusza, Tytusa, Filemona i Hebrajczyków, tł. S. Kalinkowski, ŹMT 20, Kraków 2001; Teodoret z Cyru, Leczenie chorób hellenizmu, tł. S. Kalinkowski, Warszawa 1981; Teodoret z Cyru, Listy, tł. J. Radożycki, Warszawa 1987; Teodoret z Cyru, O herezjach, tł. P.M. Szewczyk, ŹMT 77, Kraków 2016.

5 Zob. Y. Azéma, Théodoret, „Dictionnaire de spiritualité”, t. 15, kol. 418-435; W. Dobosz, Teodoret z Cyru - niedoceniany teolog z Vw., „Przegląd Piśmiennictwa Teologicznego" 22 (2016) nr 1, 5-44; T. Urbainczyk, Theodoret of Cyrrhus: The Bishop and the Holy Man, Ann Arbor 2002.

6 Theodoretus Cyrrhensis, Graecarum affectionum curatio. Prologus 1; De fide 9.

7 Theodoretus Cyrrhensis, Graecarum affectionum curatio, PG 83, 783-1152, t1. S. Kalinkowski: Teodoret z Cyru, Leczenie chorób hellenizmu, Warszawa 1981. 
artykułu w pełni ukazać specyfikę jego metody, więc będzie to jedynie krótki zarys pozwalający poznać sposób, przyczyny i cel takiej formy argumentacji, a także wskazać wnioski i wskazówki do dialogu chrześcijaństwa z filozoficznymi wyzwaniami współczesności.

\section{Kształtowanie się umysłowości i duchowości Teodoreta z Cyru}

Historyczne okoliczności życia Teodoreta pozwalają na zrozumienie, w jaki sposób wykształciła się u niego specyficzna metoda argumentacji, w której bardziej starał się uracjonalnić chrześcijaństwo niż postawić w opozycji wobec wszelkich ówczesnych poglądów na temat świata, człowieka i Boga. Teodoret z Cyru urodził się w Antiochii w dość zamożnej rodzinie chrześcijańskiej. Sam moment swoich narodzin intepretował jako znak od Boga i wyznaczenie dla niego specyficznej misji. Relacjonuje on, że jego ojciec udał się do pustelnika Macedoniusza, by ten wyprosił u Boga łaskę dziecka dla niego i jego żony. Dzięki tym modlitwom w 393 roku na świat przychodzi Teodoret, którego imię oznacza dosłownie „dar od Boga”. Od początku odbiera on bardzo dobre wykształcenie w duchu klasycznego wychowania greckiego. Poznaje, jak zauważa S. Kalinkowski, dzieła Homera, Hezjoda, Herodota, Platona, mówców attyckich, poetów lirycznych, tragików i Plotyna9. Świadectwem tego jest nie tylko kunszt erudycyjny i retoryczny jego dzieł, ale także zasób odniesień do autorów starożytnych - w dziele Leczenie chorób hellenizmu w ponad 340 miejscach nawiązuje do 100 pogańskich filozofów, historyków i poetów ${ }^{10}$. Równie ważne było także jego wychowanie duchowe, którym zajmowali się mnisi mieszkający w licznych pustelniach wokół Antiochii. Wśród swoich nauczycieli

8 Theodoretus Cyrrhensis, Historia religiosa XIII 16-17. Zob. J. Blomfield, Prolegomena, w: Nicene and Post-Nicene Fathers. Second Series, t. 3, red. P. Schaff - H. Wace, Edinburgh 1996, 1-2; I. Pásztori-Kupán, Theodoret of Cyrus, London -New York 2006, 3.

9 Kalinkowski, Wstęp, w: Teodoret z Cyru, Leczenie chorób hellenizmu, s. 5.

10 Pásztori-Kupán, Theodoret of Cyrus, s. 4; J. Ulrich, The Reception of Greek Christian Apologetics in Theodoretus" "Graecarum affectionum curatio», w: Continuity and Discontinuity in Early Christian Apologetics, red. J. Ulrich - A.C. Jacobsen - M. Kahlos, Frankfurt am Mein - Oxford 2009, 113-130. Szczegółową analizę odwołań do Platona przedstawił w swoim artykule: Marcin Karaś, Apologetyka Teodoreta z Cyru wobec filozofii Platona, „Kwartalnik filozoficzny” 23 (2003) z. 3, 33-60. 
Antiocheńczyk wymienia przede wszystkim Macedoniusza i Piotra, którzy stali się jego duchowymi mentorami. Warto zauważyć, że monastycyzm syryjski cechowała radykalna asceza stawiająca ogromny nacisk na ograniczenie ciała. Jednym z najbardziej klasycznych przykładów tej duchowości byli słupnicy na czele z Szymonem Słupnikiem ${ }^{11}$. Te dwa rysy klasycznego wykształcenia greckiego i religijnego w duchu specyficznej ascezy syryjskiej naznaczyły twórczość późniejszego biskupa Cyru. Dodatkowo znajomość zarówno języka greckiego, jak i rodzimego syryjskiego pozwoliła mu połączyć dwie różne rzeczywistości i stała się podstawą pogłębionej refleksji nad chrześcijańską teologią i duchowością ${ }^{12}$.

Wykształcenie teologiczne późniejszego biskupa Cyru ukształtowane zostało przede wszystkim przez dzieła wybitnych przedstawicieli szkoły antiocheńskiej (Św. Jana Chryzostoma, Diodora z Tarsu, Teodora

11 Zob. K. Augustyniak, Historia mnichów syryjskich, w: Teodoret biskup Cyru, Dzieje miłości Bożej. Historia mnichów syryjskich, ŹM 7, Kraków 1994, 37-53; S. Brock, Early Syrian Ascetism, „Numen” 20 (1973) 1-19; P. Canivet, Le monachisme syrien selon Théodoret de Cyr, Paris 1977; P. Canivet, Théodoret et le monachisme syrien avant le concile de Chalcédoine, Paris 1961; Ph. Escolan, Monachisme et Église. Le monachisme syrien du IVe au VIIe siècle: un monachisme charismatique, Paris 1999; S.A. Harvey, The sense of Stylite. Perspectives on Simon the Elder, VigCh 42 (1988) 376-394; W.S. McCullough, A Short History of Syriac Christianity to the Rise of of Islam, Chico 1982; P. Rousseau, Moses, monks, and mountains in Theodoret's "Historia religiosa», w: Il monachesimo tra Eredità e Aperture, red. M. Bielawski - D. Hombergen, Rome 2004, 323-346; A.M. Schor, Theodoret's People: Social Networks and Religious Conflict in Late Roman Syria, Berkeley - London 2011; K. Skotnicka, Rola modlitwy w życiu syryjskich mnichów wedtug Teodoreta z Cyru, VoxP 34 (2014) t. 65, 471-492; A. Vööbus, History of Ascetism in the Syrien Orient. A Contribution to the History and Culture in the near East, Louvain 1960; E. Wipszycka-Bravo, Wierni u stóp Symeona Stupnika. O społecznej funkcji ascetyzmu syryjskiego, RTK 26 (1979) z. 4, 91-117.

12 Zob. S. Brock, Greek and Syriac in Late Antigue Syria, w: Literacy and Power in the Ancient World, red. A.K. Bowman - G. Woolf, Cambridge 1994, 149-160; Ch. Gaşpar, Theodoret of Cyrrhus and the Glory of the Syrian Ascetics: Epic terminology in Hagiographic Contexts, ,Archaeus: Etudes d'Histoire des Religions” 4 (2000) z. 1-2, 211 240; z. 4, 151-178; F. Millar, Theodoret of Cyrrhus: a Syrian in Greek Dress?, w: From Rome to Constantinople: Studies in Honour of Averil Cameron, red. H. Amirav - R.B. ter Haar Romeny, Leuven 2007, 105-125; Y. Papadogiannakis, Christianity and Hellenism in the fifth-century Greek East. Thedoret's apologetics against the greeks in context, Cambridge - London 2012; N. Siniossoglou, Plato and Theodoret: the Christian appropriation of Platonic philosophy and the Hellenic intellectual resistance, Cambridge 2008; D. Taylor, Bilingualism and Diglossia in Late Antique Mesopotamia, w: Bilingualism in Ancient Society: Language Contact and the Written Word, red. J.N. Adams, Oxford 2002, 298-331. 
z Mopsuestii). W swoich refleksjach egzegetycznych stosował więc przede wszystkim metodę analityczną, co niestety przysporzyło mu wielu problemów, zwłaszcza w kontrowersji nestoriańskiej odnośnie do terminu

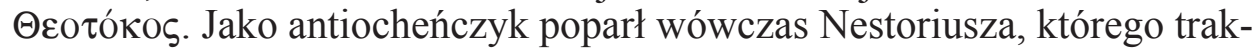
tował jako swojego serdecznego przyjaciela. W ten sposób jednak naraził się na zarzut sprzyjania herezji nestoriańskiej, z którego musiał się później tłumaczyć13.

Ważnym rysem w życiu Teodoreta, wpływającym na jego poglądy, było także jego początkowe oddanie się ascezie. Zaszczepiony przez mnichów-nauczycieli zapał monastyczny sprawił, że Teodoret w latach 416-423, jeszcze przed objęciem biskupstwa w Cyrze, wstąpił do klasztoru w Nicercie, sprzedając po śmierci rodziców cały swój majątek. Tam, oddany ascezie, budował fundamenty swojej wiary i specyficznej metody badania Pisma Świętego (synteza metody dosłownej z alegoryczną). Tam także zostały rozpoznane jego talent oratorski, wykształcenie oraz predyspozycje duszpasterskie, dzięki którym w 423 roku objął stolicę biskupią w Cyrze. Od początku musiał zmierzyć się nie tylko z dużą powierzchnią diecezji, ale przede wszystkim z licznymi heretykami, m.in. zwolennikami Eunomiusza, Ariusza, Walentyna, Montana, manichejczykami i marcjonitami. Wpłynęło to na ciągłe pogłębianie jego refleksji teologicznej i filozoficznej. Warto zwrócić uwagę, że to on współtworzył, a prawdopodobnie był głównym autorem Formuly zjednoczenia z 433 roku, która umożliwiła pogodzenie się Jana, biskupa Antiochii, i Cyryla, biskupa Aleksandrii,

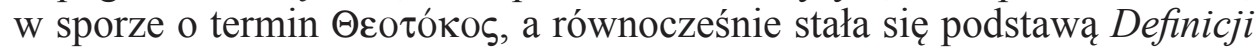
w Chalcedonie w 451 roku. W 436 roku wybuchł jednak kolejny spór chrystologiczny, którego głównym inicjatorem był Eutyches, zwolennik poglądów monofizyckich. W odpowiedzi na jego działalność Teodoret stworzył dzieło Eranistes, w którym w dialogicznej formie odrzucał poglądy monofizytów, odwołując się do kilkudziesięciu źródeł patrystycznych. Był to jednak pozorny sukces, ponieważ mimo potępienia Eutychesa w Konstantynopolu w 448 roku nieprzychylne Antiochii środowisko polityczne doprowadziło ostatecznie do depozycji Teodoreta na synodzie w Efezie w 449 roku. Antiocheńczyk, zmuszony do opuszczenia Cyru, udał się do swojego młodzieńczego klasztoru w Nicercie. Był to akt zemsty nie tylko za potępienie monofizytów, ale także za wcześniejsze opowiedzenie się po stronie Nestoriusza w jego sporze z Cyrylem, czego świadectwem jest dzieło Odparcie dwunastu anatematyzmów ${ }^{14}$. W 451 roku w Chalcedonie Teodoret został zrehabilitowany i wrócił na swoją stolicę biskupią. Umarł

13 Por. J. Blomfield, Prolegomena, s. 3; R.J. Perchai, Antiochene Theoria in the Writings of Theodore of Mopsuestia and Theodoret of Cyrus, Augsburg 2015, 33-112.

14 Theodoretus Cyrrhensis, Reprehensio XII capitum, PG 76, 385-452. 
między 457 a 466 rokiem, ale konflikt Antiochii z Aleksandrią trwał nadal, czego kulminacją było jego pośmiertne potępienie na piątym soborze w Konstantynopolu w 553 roku w ramach tzw. trzech rozdziałów ${ }^{15}$, czyli Listu Ibasa z Edesy do Marysa, nauki Teodora z Mopsuestii oraz trzech najbardziej sprzeciwiających się naukom Cyryla dzieł Teodoreta (Refutatio, Pentalogos, Apologia ad Diodorem et Teodorem). To wydarzenie spowodowało, że nie tylko te, ale także wiele $\mathrm{z}$ ważnych dogmatycznych dzieł Teodoreta zaginęło lub zostało zniszczonych. Współczesna analiza lingwistyczna i stylistyczna pozwoliła jednak odnaleźć część z nich ukrytych w pseudoepigrafiach ${ }^{16}$.

\section{Kontekst historyczno-społeczny apologii}

Pierwsza apologia ${ }^{17}$ Teodoreta Leczenie chorób hellenizmu wpisuje się w nurt obrony chrześcijaństwa zapoczątkowany w II wieku przez Justyna Męczennika polegający na poszukiwaniu punktów wspólnych z grecką filozofią, zwłaszcza Platońską, i uzasadnienia chrześcijaństwa jako prawdziwej filozofii, a nawet punktu kulminacyjnego poszukiwania mądrości ${ }^{18}$. Ten sposób postępowania wynikał przede wszystkim z krytyki pochodzącej z greckiego środowiska intelektualnego (Celsus, Lucjan z Samosaty), które zarzucało nauce chrześcijańskiej brak racjonalności i budowało w społeczeństwie przekonanie, że jedynym sposobem jej uzasadniania było odniesienie do Boga jako prawodawcy wszelkich doktryn ${ }^{19}$.

W Dialogu z Żydem Tryfonem Justyn, analizując własną drogę przemiany swojego myślenia z filozoficznego na chrześcijańskie, udowadnia, że jedyną godną zaufania filozofią jest nauka Chrystusa. Uzasadniając swoje stanowisko, wskazuje na patologie, które drążyły ówczesne szkoły filozoficzne, dla których poszukiwanie mądrości przestało być duchowym ćwiczeniem, sposobem życia, a stało się zawodem, źródłem zarobku i możliwością uzyskania czci w społeczeństwie. Chrześcijaństwo było więc dla Justyna powrotem do filozofii szeroko rozumianej, łączącej dą-

15 R. Price, The Three Chapters Controversy and Council of Chalcedon, w: The Crisis of the Oikoumene: The Three Chapters and the Failed Quest for Unity in the SixthCentury Mediterranean, red. C. Chazelle - C. Cubit, Turnhout 2007, 17-37.

16 Zob. Dobosz, Teodoret z Cyru, s. 5-44.

17 Papadogiannakis, Christianity and Hellenism, s. 4.

18 Por. L. Misiarczyk, Wstęp. Apologetyka wczesnochrześcijańska, w: Pierwsi Apologeci Greccy, BOK 24, Kraków 2004, 5-91.

19 Zob. G. Karamanolis, The Philosophy of Early Christianity, Acumen 2013, 29-59. 
żenia intelektualne z egzystencjalnymi, a Pismo Święte stało się źródłem prawdziwej wiedzy, gdyż odpowiadało na pytania, które od początku zadawali filozofowie. Metoda, którą posłużył się Justyn w celu zbliżenia chrześcijaństwa z kulturą grecką, polegała na uracjonalnieniu tajemnicy wiary (poprzez wskazanie na jej pełną logiczność i możliwość rozumowego zgłębienia), a także na uzasadnieniu przekonania, że poprzez intuicję można dotrzeć do tej samej prawdy o istnieniu Boga i ludzkiej natury, która zawarta jest w Objawieniu ${ }^{20}$. Justyn w swoich Apologiach oraz w Dialogu z Żydem Tryfonem nie ogranicza się tylko i wyłącznie do zebrania takich twierdzeń filozofów, które uzasadniają prawdę chrześcijańską, ale przede wszystkim posługuje się samą filozofią, by stworzyć szkielet pod dyskursywny przekaz wiary. Miarą wiarygodności filozofii jest bowiem według niego jej skuteczność w budowaniu człowieka doskonałego ${ }^{21}$. Akcentowanie zgodności doktryny z rozumem było naturalnym (odpowiadającym ówczesnej mentalności) sposobem dotarcia do pogańskiej części społeczeństwa, dla której argumenty pochodzące wprost z natchnionych Pism lub wiary były mało zrozumiałe. Głównym celem apologety było przekonanie elit intelektualnych Cesarstwa, że filozofia, która jest $\mathrm{w}$ relacji $\mathrm{z}$ rozumem, równocześnie na tej samej zasadzie jest połączona $\mathrm{z}$ wiarą - wiara i rozum to dwa dopełniające się, a więc równoważne spojrzenia na jedną prawdę ${ }^{22}$. Chrześcijaństwo było więc nadprzyrodzonym uzupełnieniem filozofii greckiej, było jej ostatecznym wypełnieniem. Mędrcy greccy otwarci na boski Logos zawarty W naturze stanowili więc zalążek chrześcijaństwa ${ }^{23}$. Niektórzy z nich, jak Sokrates czy Heraklit, żyjąc zgodnie ze swoimi przekonaniami, byli według Justyna jakby chrześcijanami, chociaż uznani zostali za ateistów ${ }^{24}$. Apologeta twierdzi wręcz, że w takim wypadku prawowitymi dziedzica-

20 Por. E.J. Hunt, Christianity in the Second Century, Routledge, London - New York 2003, 5-18, 52-73; W. Jaeger, Wczesne chrześcijaństwo i grecka paideia, tł. K. Bielawski, Bydgoszcz 2002, 48-52; K. Pawłowski, Spotkanie starożytnego chrześcijaństwa z filozofia grecka w czasach Justyna Męczennika i Klemensa Aleksandryjskiego, CT 86 (2016) 69-84.

21 Por. G.J. Zakrzewski, Filozofia antyczna w pierwotnym chrześcijaństwie, Lublin 2013, 78 .

22 Por. B. Pouderon, Les apologetics chrétiens et la culture greque, Paris 1998.

23 Zob. J.N.D. Kelly, Poczatki doktryny chrześcijańskiej, tł. E. Stanula, Warszawa $1988,80-84,115$.

24 Por. J.E. Wróblewska, Św. Justyn, ,Sprawiedliwy pośród narodów”, VoxP 32 (2012) t. 57, 751-754. Zob. R.M. Leszczyński, Starożytna koncepcja Logosu i jej wptyw na myśl wczesnego chrześcijaństwa, Warszawa 2003, 214-255; Zakrzewski, Filozofia, s. 50-51. 
mi nauk Greków, których jedynym źródłem jest wcielony Logos - Jezus Chrystus, są tylko i wyłącznie chrześcijanie ${ }^{25}$.

Klemens Aleksandryjski kontynuował ten nurt apologetyczny. W swoich dziełach podkreślał rolę Logosu jako nauczyciela i wychowawcy (dzieło Pedagog), który uczył Greków prawdy w ramach ich sposobu myślenia, a także jako lekarza, który uzdrawiał z moralnej choroby i pomagał powstrzymać się od grzechów ${ }^{26}$. Podobnie jak Justyn przedstawiał on chrześcijaństwo jako wypełnienie filozofii klasycznej. Aleksandryjczyk metody i poglądy filozofów traktował jako narzędzia, które umożliwiały nie tylko wydobycie z Objawienia fundamentów filozofii chrześcijańskiej, ale również pełniejsze odkrycie przedstawionych w nim prawd. Filozofia według aleksandryjczyka miała pełnić rolę służebną wobec chrześcijaństwa, co wydaje się być początkowym etapem kształtowania się nowego rozumienia teologii jako rozumowej refleksji nad wiarą, a nie jak dotychczas jako tworzenia mitów i opowiadań dotyczących bóstw ${ }^{27}$. W ten sposób miała ona stać się skuteczną pomoca w ewangelizacji pogan ${ }^{28}$. Podobnie jak Justyn i Klemens uważa, że etapem, który doprowadził do odkrycia prawdy przez filozofów, była akceptacja Prawa żydowskiego jako źródła wiarygodnej nauki. Platon określany jest przez niego jako Mojżesz Greków, który odkrywa krok po kroku prawdę, na która jest otwarty ${ }^{29}$. Kolejnym etapem poszukiwania mądrości powinno być przyjęcie wiary w Chrystusa jako punktu kulminacyjnego, a następnie oddanie się kontemplacji Boga, która przemienia nie tylko intelektualnie, ale i moralnie w człowieka doskonałego. Klemens w swoim dziele Kobierce wymienia metody prowadzenia ćwiczeń duchowych i umysłowych obecne w filozofii klasycznej, przeszczepiajac je do chrześcijaństwa i wskazując na ich rolę we wzroście wiary polegającym na ciągłym poszerzaniu rozumienia nauki Objawienia. Celem takiego procesu było ukształtowanie gnostyka - człowieka, który doszedł do

25 Por. Pawłowski, Spotkanie starożytnego chrześcijaństwa, s. 69-84.

26 Por. Leszczyński, Starożytna koncepcja Logosu, s. 313-377; J. Pałucki, Chrystus Boski Lekarz w Pismach Klemensa Aleksandryjskiego, w: Wczesnochrześcijańska asceza. Zagadnienia wybrane, red. F. Drączkowski - J. Pałucki, Lublin 1993, 19; B. Zgraja, Chrystus Boski Logos - wzór i mistrz cnoty wedtug Klemensa Aleksandryjskiego, SW 47 (2010) 49-69.

27 M. Fiedorowicz, Teologia Ojców Kościoła. Podstawy wczesnochrześcijańskiej refleksji nad wiara, Kraków 2009, 27.

28 Por. Zakrzewski, Filozofia, s. 101-103.

29 Por. F. Drączkowski, Wychowawcza funkcja Prawa Starego Testamentu w koncepcji Klemensa Aleksandryjskiego, RTK 26 (1979) z. 3, 17-18; Pawłowski, Spotkanie starożytnego chrześcijaństwa, s. 72. 
pełnego poznania wiedzy, nauki chrześcijańskiej i oddał się kontemplacji prawdy. Klemens jest przedstawicielem eklektyzmu, a zatem korzystał z całego dorobku intelektualnego ówczesnego czasu i wybierał z niego to, co dobre ${ }^{30}$. Boski Logos bowiem działał w świecie także przed wcieleniem, ucząc ludzi tego, co wartościowe. W momencie Jego objawienia w Jezusie Chrystusie jedyną godną filozofa postawą było otwarcie się i uznanie w Nim żywego Logosu, źródła wszelkiej mądrości i dobra.

Przekonanie, że chrześcijaństwo jest jedyną prawdziwą filozofią i powinno być jedynym wyborem drogi życia dla każdego Greka i poganina, było rozwijane także w apologetyce IV wieku, zwłaszcza w nauce Ojców Kapadockich. Bazyli i Grzegorz z Nazjanzu, mając pozytywny stosunek do dorobku hellenizmu, uzasadniali podobnie jak poprzednicy, że filozofia starożytna była przygotowaniem do przyjęcia Ewangelii - filozofii jedynej i prawdziwej. W swoich dziełach konfrontowali teksty wybitnych myślicieli starożytnych z nauką Pisma Świętego, aby udowodnić jego wiarygodność i pokazać nieracjonalność niektórych poglądów filozoficznych ${ }^{31}$. Bazyli dostrzegł także szansę, by niektóre poglądy, zwłaszcza Arystotelesa, po odpowiednim przygotowaniu schrystianizować ${ }^{32}$.

Filozofia była dla Kapadocczyków nie tylko sumą poglądów różnych szkół, ale przede wszystkim postawą człowieka wobec jedynej prawdy. Różne sposoby odpowiedzi na tę prawdę były konsekwencją braku Objawienia, które w osobie Jezusa Chrystusa ostatecznie dopełniło wszelkich poszukiwań. Umiłowanie mądrości było dla nich procesem, w którym Bóg objawia się człowiekowi, ale tylko wtedy, gdy ten potrafi otworzyć się na prawdę i według niej żyć33. Spośród Kapadocczyków najbardziej pod względem filozoficznym wyróżniał się Grzegorz z Nyssy, który nie tylko cytował i porównywał naukę filozofów starożytnych z chrześcijańską, ale starał się dopasować ją do nauki Pisma Świętego. Stosując znane pojęcia filozoficzne, starał się przeredagować chrześcijańskie prawdy, by mogły być porównane z dotychczasowymi systemami. Grzegorz chciał w sposób filozoficzny ukazać nowość i niezbędność perspektywy chrześcijańskiej ${ }^{34}$. Ojcowie Kapadoccy otworzyli nowy etap obrony obecności chrześcijaństwa

30 Por. Fiedorowicz, Teologia Ojców Kościoła, s. 38-41; N. Widok, Koncepcja eklektyzmu Klemensa Aleksandryjskiego, STHŚO 14 (1993) 25-37.

31 Por. Fiedorowicz, Teologia Ojców, s. 111, 140, 242-244; Ł. Leonkiewicz, Wybrani Ojcowie Kościoła wobec filozofii starożytnej (cz. II), „Elpis” 16 (2014) 78-79.

32 Por. Leonkiewicz, Wybrani Ojcowie, s. 78.

33 Por. Leonkiewicz, Wybrani Ojcowie, s. 80-81.

34 Por. W. Szczerba, Tradycja filozoficzna a Biblia w Kościele pierwszych wieków. Casus Grzegorza z Nyssy, „Theologica Vratislaviensia” 2 (2007) 139-141. 
w Cesarstwie, starając się przeinterpretować kulturę antyczną, by zyskała ona nowy, Chrystusowy sens ${ }^{35}$.

Teodoret z Cyru kontynuuje tradycję apologetyczną polegającą na pojednaniu chrześcijaństwa $\mathrm{z}$ hellenizmem. Korzystając z dorobku Justyna, Klemensa Aleksandryjskiego i Ojców Kapadockich, tworzy apologię Leczenie chorób hellenizmu, która według J. Quastena stała się jedną z najlepszych i zarazem ostatnich apologii próbujących pojednać filozofię i wia$\mathrm{rę}^{36}$. W jego dziele można zauważyć zarówno elementy pochodzące $\mathrm{z}$ metody Justyna, dla którego chrześcijaństwo było jedyną prawdziwą filozofią, jak i Klemensa, który poszukiwał wśród autorów greckich tych, którzy potwierdzali wiarygodność i racjonalność wiary, Objawienia, nauk Pisma Świętego, a więc uzasadniały pozycję chrześcijaństwa w obrębie filozofii. Najbardziej jednak widać wpływ Ojców Kapadockich, przede wszystkim Grzegorza z Nyssy, który próbował przeinterpretować kulturę antyczną w kategoriach chrześcijańskich.

Teodoret $\mathrm{w} \mathrm{V}$ wieku staje przed problemami zarówno istniejącymi już na styku chrześcijaństwa i hellenizmu, jak i nowymi. W społeczeństwie nadal żywy był wpływ pogańskich polemik z chrześcijaństwem, przede wszystkim krytyki Porfiriusza oraz dzieła cesarza Juliana Przeciw Galilejczykom $^{37}$. Hellenizm próbował się przeinterpretować, by w konflikcie z chrześcijaństwem nie utracić swego wpływu na społeczeństwo. Pomimo tego, że w IV wieku wiara w Chrystusa stała się religią panującą, nadal cała edukacja helleńska, w której uczestniczyła elita intelektualna Cesarstwa, opierała się na wzorach starożytnych. Studenci musieli zapoznawać się z dziełami filozofów i retorów, z całym dorobkiem literatury antycznej, przy których prosta nauka Chrystusa była mniej atrakcyjna, skromna ${ }^{38}$. Grecka kultura literacka była wskaźnikiem tożsamości obywateli Cesarstwa. W kontekście chrystianizacji wykształcone elity oczekiwały więc nie tyle odrzucenia dotychczasowego dorobku kulturowego, co wskazówek, w jaki sposób w nowych realiach mogłyby z niego dalej korzystać. Dodatkowym wyzwaniem były także grupy pseudokonwertytwów, które zmuszone do zmiany przekonań religijnych nadal pozostawały przy

35 Por. Leonkiewicz, Wybrani Ojcowie, s. 78-81; S. Longosz, Wstep, w: Św. Bazyli Wielki, Do młodzieńców o pożytkach z czytania książek pogańskich, VoxP 32 (2012) t. 57 , 899.

36 Zob. J. Quasten, Patrology vol. 3 The Golden Age of Greek Patristic Literature: From the Council of Nicea to the Council of Chalcedon, Westminster 1992, 543.

37 Ch. Gaşpar, An oriental in Greek dress: the making of a perfect christian philosopher in the "Philothetos Historia» of Theodoret of Cyrrhus”, „Annual Medieval Studies” 14 (2008) 195.

38 Papadogiannakis, Christianity and Hellenism, s. 17-18, 26-28. 
kulcie dotychczasowych bóstw. Problemem były także napięcia ze strony judaizmu, który stanowił najbliższą dla wyznawców Chrystusa atrakcyjną alternatywę, wspólnot heretyckich oraz prześladowań perskich za czasów króla Yazdgarda I (399-421) $)^{39}$. Taka sytuacja wymagała jasnego określenia chrześcijańskiego fundamentu w nowych, rodzących niepewność wyznawanej wiary warunkach.

Teodoret musiał więc zmierzyć się z pytaniem, w jaki sposób hellenizm może znaleźć miejsce w chrześcijaństwie, czy w ogóle możliwe jest współżycie lub synteza tych dwóch sposobów myślenia. Odpowiedź na to pytanie była niezbędna, by przekonać zarówno zatwardziałych pogan, jak i poszukujących uzasadnienia swojej wiary neofitów. Teodoret w odpowiedzi na wyzwania stara się nie tylko znaleźć punkty wspólne pomiędzy hellenistyczną filozofią i kulturą a Pismem, ale dąży do chrześcijańskiego przedefiniowania Cesarstwa - związania chrześcijaństwa z hellenizmem. Jego głównym sposobem realizacji powyższego celu jest obrona kultu męczenników, a także asymilacja idei ascetyzmu w nowej rzeczywistości Imperium $^{40}$.

Hellenizm walczył z chrześcijaństwem, prezentując w biografiach i historiografiach filozofów jako figury religijne o nienagannej moralności, pełne cnót, gotowe do wyrzeczeń, pobożne i dążące do zjednoczenia z Bogiem. Takimi pismami były np. Żywot Plotyna, Żywot Pitagorasa Porfirusza, Żywot Proklusa Marinusa, Żywot Izydora Damasciusa. Bohaterami tych biografii byli jednak tylko i wyłącznie wybitni przedstawiciele helleńskiej kultury i religii. Pozostawiały więc wrażenie, że osiągnięcie pełni doskonałości, boskiego statusu jest możliwe przede wszystkim w ramach hellenizmu ${ }^{41}$. W ten sposób tradycje hellenizmu nadal miały istotny wpływ na sposób życia obywateli Imperium, którzy już w większości przyjęli chrześcijaństwo. Teodoret zdawał sobie sprawę, że literatura i kultura jest miejscem spotkania chrześcijaństwa $\mathrm{z}$ hellenizmem. Był również świadomy tego, że kultura grecko-rzymska stanowiła istotę tożsamości ówczesnego społeczeństwa. Nie mógł więc wprost odrzucić jej dorobku, tak jak uczynił to z kultami pogańskimi, ale szukał syntezy, która zapewniłaby naturalne przejście od kultury pogańskiej do chrześcijańskiej. Wiara w Chrystusa miała stać się podstawą tożsamości Imperium przy poszanowaniu dla dotychczasowej tradycji ${ }^{42}$. Leczenie wychodzi naprzeciw tym wyzwaniom i stanowi kamień milowy w tworzeniu chrześcijańskiej „paidei”. Jego dzieło jest doskonale zbudowane - skiero-

39 Papadogiannakis, Christianity and Hellenism, s. 21-22.

40 Gaşpar, An oriental in Greek dress, s. 194-195.

41 A. Cameron, The Last Pagans of Rome, New York 2011, 644-654, 668-678.

42 P. Rousseau, Late Roman Christianities, w: The Cambridge History of Christianity, t. 3, red. T.F.X. Noble - J.M.H. Smith, Cambridge 2008, 36-38. 
wane do wykształconych elit, przekształca opowieści biblijne w logikę i nomenklaturę helleńską, a chrześcijaństwo ukazuje jako jedyną możliwość wyboru dla wzorcowo wyedukowanego obywatela Cesarstwa ${ }^{43}$.

Teodoret Leczenie chorób hellenizmu buduje wokół koncepcji rozumu jako naturalnej drogi do wiary. Przejawem tego jest przekonanie, że Platon był tym, który podprowadził filozofię na próg chrześcijaństwa, jednak nie potrafił postawić kolejnego kroku, którym była wiara. W dziele tym, napisanym w klasztorze w Nicercie, stara się więc przede wszystkim uleczyć chorobę niewiary, która niczym mgła osłaniała umysły filozoficznie ukształtowanych Greków, starając się ukazać blask „rozumnej światłości” (voepo v̂ $\varphi \omega \tau \grave{\varsigma} \varsigma)^{44}$, którym dla Teodoreta jest chrześcijaństwo odkrywające prawdę o świecie stworzonym przez jednego Boga. Leczenie nosi w sobie rysy młodzieńczego zapału i zafascynowania się światem mnichów, których traktuje jako wzór rozumowej kontemplacji prawdy, ale także zapatrzenia się w klasyczną kulturę grecką, w której widzi zarzewia wiary. Specyficzny apologetyczny radykalizm buduje styl dzieła, który nie ma na celu potępienia myśli greckiej, ale wyprowadzenie z niej naturalnej drogi ku wierze, która dla młodego mnicha jest warunkiem poznania pełnej prawdy o świecie ${ }^{45}$. Ch. Gaşpar ten oryginalny styl poddaje dokładnej analizie, zwłaszcza od strony lingwistycznej, zestawiając go równocześnie z późniejszym i dojrzalszym (powstałym ok. 444 roku) dziełem Dzieje Bożej Miłoścít ${ }^{46}$.

\section{Kryteria racjonalności nauki}

Próba uzasadnienia racjonalności chrześcijaństwa stanowiła początek refleksji Teodoreta, który w ten sposób próbował zjednać dla wiary chrze-

43 Papadogiannakis, Christianity and Hellenism, s. 28-29; Gaşpar, An oriental in Greek dress, s. 194-195.

44 Theodoretus Cyrrhensis, Graecarum affectionum curatio. De fide 6.

45, ,...] nie wolno lekceważyć ludzi niszczonych chorobą, ale trzeba szukać wszelkiego sposobu, aby rozproszyć okrywającą ich mgłę i pokazać im blask rozumnej światłości” (Theodoretus Cyrrhensis, De fide 6).

46 W swoim artykule poddaje bardzo dokładnej analizie oba dzieła i ukazuje rozwój duszpasterskiego zmysłu Tedoereta, który dla obrony chrześcijaństwa wykorzystuje attycki styl grecki, którym doskonale włada, by za jego pomocą przedstawić nauki mnichów jako niezwykle subtelną filozofię. Jest to niezwykle interesujące pod tym względem, że słabo wykształceni, często nieznający w ogóle języka greckiego mnisi, w dziele Teodoreta okazują się być klasycznie wykształconymi przedstawicielami helleńskiej kultury. Zob. Gaşpar, An oriental in Greek dress, s. 193-229. 
ścijańskiej dobrze wykształconych Greków. Jego argumentacja miała na celu przede wszystkim ukazanie wyznawców Chrystusa jako prawdziwych filozofów, którzy w najwyższym stopniu opanowali mądrość polegającą na ciągłym poszukiwaniu prawdy. Teodoret odwołuje się w tym kontekście do uznanej w klasycznie wykształconych warstwach greckich definicji, zaczerpniętej od Platona, która głosi, że filozof to ten myśliciel, którego umysł nieustannie zadaje pytania dotyczące prawdy rzeczywistości, którą

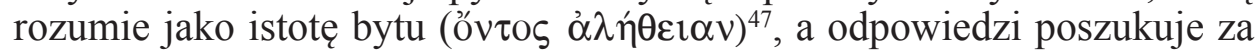
pomoca wiedzy i prawdy ${ }^{48}$. Taka argumentacja była odpowiedzią na zarzuty Greków, którzy traktowali chrześcijaństwo jako niepoważną naukę rybaków, pozbawioną logiki i wykraczającą poza zasady ogólnie przyjętego rozumowania: ,[...] twierdzili, że adeptom naszej religii nie dajemy nic poza przykazaniem wiary, oskarżali apostołów o nieuctwo i nazywali ich barbarzyńcami, którzy nie umieją się elegancko wysłowić"49. Chrześcijaństwo było więc postrzegane jako pozbawiona jakiegokolwiek uzasadnienia nauka, która aspiruje do tego, by być filozofią, ale jej jedynym argumentem jest nakaz i słowo Boże, które nie stanowi wymiernego znaczenia dla filozofii greckiej. Teodoret podejmuje polemikę z takim stanowiskiem, nawiązując do doświadczeń kultury greckiej i sposobu oceny wartości dzieł jako sensownych. Próbuje stworzyć ogólne kryteria racjonalności nauki, by później wykorzystać je przy rzetelnej ocenie chrześcijaństwa.

Cyreńczyk swoją analizę rozpoczyna od określenia, czy źródło, pochodzenie danej nauki stanowi o jej wartości poznawczej. Odwołuje się więc do świadectwa uznanych filozofów (m.in. Ferekidesa z Syros, Pitagorasa z Samos, Talesa z Miletu, Solona, Platona), którzy nie obawiali się nauk pochodzących spoza Grecji, a nawet z krajów o odmiennym ustroju politycznym (np. rządzonych przez tyrana), ale starali się znaleźć w nich prawdę. Ryzykowali nawet życie, by podróżować po całym świecie w celu znalezienia prawdy i nie wahali się przyjąć nauk o sprawach, „, [...] które w ich przekonaniu barbarzyńcy znali lepiej niźli oni" ${ }^{50}$. Samo greckie pochodzenie danej nauki nie oznaczało więc jej prawdziwości i wartości, ponieważ wówczas kultura grecka byłaby znacznie uboższa. Teodoret, by dodatkowo uzasadnić swoje twierdzenia, wymienia konkretne elementy z innych kultur, które przejęli Grecy: od Egipcjan geometrię, od Chaldejczyków astrologię i horoskopy, od Fenicjan alfabet, trąbę od Tyreńczyków, sztukę lekarską od Egipcjanina Apisa ${ }^{51}$. Dla filozofów przede wszystkim miały

\footnotetext{
47 Theodoretus Cyrrhensis, De fide 9.

48 Theodoretus Cyrrhensis, De fide 33.

49 Theodoretus Cyrrhensis, Prologus 1.

50 Theodoretus Cyrrhensis, De fide 12.

51 Theodoretus Cyrrhensis, De fide 12.
} 
znaczenie świadectwo i wartość danej nauki, niezależnie od tego, skąd pochodziła. Kryterium oceny polegało na konfrontacji z prawdą - czy dana nauka przybliża do niej czy od niej oddala. Apologeta w ten sposób odrzucił zarzut barbarzyńskich źródeł chrześcijaństwa, którego greckiego pochodzenia nie udało się uzasadnić, a równocześnie pozytywnie wskazał na naukę Pisma Świętego jako drogę do odkrycia prawdy, a więc z filozoficznego punktu widzenia wartą wysłuchania.

O racjonalności danej nauki nie świadczył także sam rodowód czy wykształcenie nauczyciela, ale przede wszystkim harmonia i prostota jego nauki. Antiocheńczyk wskazuje na liczne postacie greckiej kultury, m.in. Talesa, Pitagorasa, Ferekidesa, Arystoksenosa, Arystarcha czy Teopompa, a nawet Arystotelesa, którzy, choć urodzili się poza Grecją, zostali uznani za wybitnych przedstawicieli kultury helleńskiej ${ }^{52}$. Według Teodoreta, „słuchając muzyka grajacego na kitharze wymagają od niego wyłącznie harmonii dźwięków, a nie starają się dociekać, czy artysta [uczeń] jest Grekiem, czy barbarzyńca,"53. Biskup z Cyru odrzuca, powołując się na autorytet Platona, wszelkie pozory naukowości, którymi są piękno języka, bogactwo sofistycznych ozdób i retorycznych figur. Dla mędrca prawda nie tkwi w pięknie języka, ale w prawdzie treści. Może więc zostać sformułowana w najbardziej prymitywnych słowach i formach, jeżeli tylko przedstawia harmonię myśli i ład w rozumowaniu. „Przede wszystkim jednak uleczmy chorobę zarozumiałości. Niektórzy bowiem ludzie, zapoznawszy się ze słowami poetów i mówców albo skosztowawszy pięknego stylu Platona, gardzą słowami Bożymi, dlatego tylko, że brakuje im ozdób pięknego wysłowienia; za rzecz niegodną uważają uczyć się prawdy o bycie od rybaków" ${ }^{54}$. Antiocheńczyk zauważa, że największymi przeciwnikami chrześcijaństwa nie byli wybitni filozofowie, ale najczęściej osoby, które zapoznawszy się z niewielkim zakresem wiedzy o świecie i prawdzie, popadały w zarozumiałość i formułowały bardzo radykalne stwierdzenia wobec kultur barbarzyńskich, traktując je jako zupełnie pozbawione rozumu. Problem nie polegał więc przede wszystkim na kwestii pochodzenia nauki, ale na nastawieniu samego filozofa. Dlatego też Teodoret, analizując poglądy niektórych myślicieli, nie tylko wykazuje niedorzeczność ich zarzutów, przedstawiając kontrargumenty, ale wskazuje na ich głębszą przyczynę - pychę wynikającą z samozachwytu nad własnymi dokonaniami: „Otworzyć oczu nie pozwala im choroba zarozumiałości. Wydaje się im, że znają prawdę lepiej niż wszyscy inni ludzie, bo nakarmili się

\footnotetext{
52 Theodoretus Cyrrhensis, De fide 23-24.

53 Theodoretus Cyrrhensis, De fide 11; 50.

54 Theodoretus Cyrrhensis, De fide 9.
} 
naukami przesławnych mężów [...]"55. Taka dokładna analiza umożliwiła antiocheńczykowi znalezienie źródła problemów jątrzących umysłowość helleńską oraz usunięcie przyczyny wadliwego myślenia.

Pismu Świętemu jako niespisanemu po grecku zarzucano zbytnią prostotę językową i myślową, jednak Teodoret udowadnia, że biegłość w klasycznej sztuce wymowy nie stanowiła kryterium wartości danej nauki. Sofistyczna łatwość używania retorycznych figur wprawdzie wzbudzała zachwyt i podziw, zwiększając liczbę zwolenników, ale jednocześnie mogła zakrywać prawdę, manipulując nią i zatrzymując proces myślenia, dlatego wybitni filozofowie, jak Sokrates, odrzucali piękno wysłowienia ${ }^{56}$, wskazując przede wszystkim na zrozumiałość, przybliżenie słuchacza do

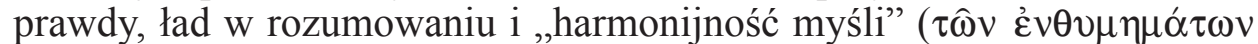

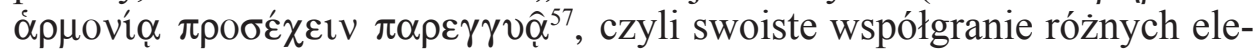
mentów, brak wzajemnie wykluczających się tez, a więc niesprzeczność). Największym zagrożeniem pięknych, pełnych elegancji wypowiedzi był pozór rozumności, pod którym mogło kryć się kłamstwo. Antiocheńczyk, sam wychowany na attyckim stylu, który obfitował w figury retoryczne i sylogizmy, nie krytykuje go jako u podstaw złego. Sam zachwyca się nim i intepretuje jako dar Boży, ale jest świadomy, że jako narzędzie może zostać on wykorzystany zarówno do dobrego, jak i złego ${ }^{58}$. Dlatego też jest zwolennikiem prostoty wypowiedzi, pod którą nie ukryje się kłamstwo. Jako kryterium uznaje przede wszystkim ład w rozumowaniu, sensowność, trafność wypowiedzi. Teodoret uważa, że każdą naukę trzeba pozbawić zbędnych ozdobników i analizować wprowadzane tezy, ponieważ tylko w ten sposób można sprawdzić, czy jej twierdzenia zbliżają ku prawdzie czy też zupełnie się wykluczają - ,[...] łatwość wysłowienia nie zawsze jest nauczycielką prawdy" 59 . W tym kontekście dla autora Leczenia chorób

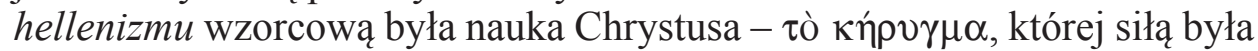
prawda przekazana $\mathrm{w}$ zrozumiałej, nieskomplikowanej formie, a ,ogromna moc" była ukryta pod prostotą przekazu. Nauka Ewangelii dzięki swej prostocie była łatwo przetłumaczalna na inne języki, a jednocześnie od słuchacza nie wymagała głębokiego wykształcenia, gdyż przekazywała prawdy dostępne każdemu, kto używał rozumu. W konsekwencji Teodoret nie obawia się stwierdzić, występując także przeciwko swoim umiejętnościom:

55 Theodoretus Cyrrhensis, De principio 5.

56 Zob. Theodoretus Cyrrhensis, De fide 26-30.

57 Theodoretus Cyrrhensis, De fide 32.

58 Theodoretus Cyrrhensis, Interpretatio in quattuordecim epistulas S. Pauli. Prima epistola ad Corinthios I 1, 20b.

59 Theodoretus Cyrrhensis, Graecarum affectionum curatio. De principio 6. 
Litujemy się nad ich głupotą: widząc ludzi mówiących po barbarzyńsku, którzy zwyciężyli piękno greckiego wysłowienia, widząc, jak pięknie skomponowane mity zostały całkiem poniechane, a attyckie sylogizmy(A

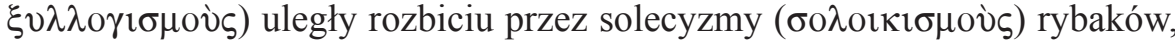
nie okazują wstydu i nie siedzą cicho, lecz bez skrępowania walczą w obronie błędu! ${ }^{60}$.

Proste, często pełne błędów językowych, wypowiedzi rybaków siłą prawdy pozbawionej wszelkich ozdobników (jak podkreśla Teodoret nagiej) zwyciężyły greckie skomplikowane rozumowania. Według antiocheńczyka historia zaświadcza, że w zbiorowej pamięci przetrwały nauki Pisma Świętego, przenikając do powszechnej świadomości, a tezy filozofów, jeżeli nie były z nimi zgodne, zostały zapomniane ${ }^{61}$.

Ocena rozumności twierdzeń filozofa nie była również uzależniona od poziomu opanowania przez niego klasycznego greckiego kanonu nauk. Teodoret $\mathrm{w}$ tym kontekście odwołuje się do Platońskiej definicji filozofii - „Filozofia bowiem nie tkwi w geometrii, opartej na założeniach i hipotezach, nie tkwi też w muzyce, która polega na domysłach, ani w astronomii, w której pełno jest pojęć fizycznych, płynnych i prawdopodobnych; tkwi ona $\mathrm{w}$ poszukiwaniu istoty dobra za pomocą wiedzy i prawdy" ${ }^{2}$. Wiedza naukowa i umiejętności to dla Teodoreta jedynie elementy wspomagające, bez których dojście do istoty rzeczywistości jest możliwe. Wykształcenie nie było więc elementem niezbędnym na drodze do mądrości. Przede wszystkim musiało ono być ciągle weryfikowane wobec prawdy, tzn. pod względem zgodności z rzeczywistością. Wiedza mogła być pomocna tylko wtedy, gdy była ciągle otwarta na odkrywana prawdę. Jeżeli więc celem poszukiwania prawdy jest dobro idealne, dobro samo w sobie ( $\alpha$ v $\tau$ o$\alpha \gamma \alpha \theta$ ós), to znaczy, że konfrontacja z prawdą ma kształtować filozofa moralnie, przemieniać go bytowo. Kryterium wiarygodnej nauki nie stanowi więc posiadane przez nauczyciela wykształcenie, ale jego postawa wobec odkrytej prawdy. Jeżeli swoje życie kształtuje według tego, co głosi, a jednocześnie odkryte prawdy budują w nim doskonałość w cnocie (to, co dobre), to uwiarygadnia siebie jako rzetelnego filozofa znajdującego się na drodze prawdziwej mądrości - odkrywania prawdy samej w sobie ${ }^{63}$.

Wiedza według Teodoreta staje się poważnym utrudnieniem na drodze do poznania prawdy wtedy, gdy filozof, skupiając się tylko na tym, co już

60 Theodoretus Cyrrhensis, De natura hominis 64.

61 Theodoretus Cyrrhensis, De natura hominis 60-62.

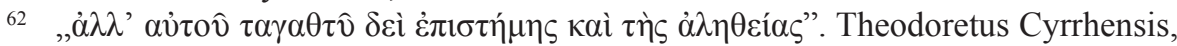
De fide 32 .

63 Theodoretus Cyrrhensis, De fide 34. 
osiągnął, ulega zarozumiałości i odrzuca wszystkie pozostałe nauki, które uzna za prostackie, ale również wówczas, gdy koncentrując swój umysł na nieistotnych szczegółach, odwróci uwagę od głównego celu, którym jest odkrycie prawdy. Teodoret, nawiązując do Platona, jako wzór myślenia filozoficznego określa prostych, niewykształconych ludzi, którymi byli pasterze. Nieistotna zupełnie dla nich jest ilość posiadanej na własność ziemi, gdyż są przyzwyczajeni do spoglądania na cały piękny świat. Umysł wolny od niepotrzebnej wiedzy potrafi więc przezwyciężyć pokusę posiadania i otworzyć się na szeroki horyzont myślenia, na patrzenie holistyczne na rzeczywistość, a w związku z tym przybliżyć się do prawdy bytu. Teodoret w ten sposób wskazuje, że apostołowie, choć nie posiadali wykształcenia, mieli wszystkie predyspozycje, by stać się odbiorcami i przekazicielami prawdy. Jako prości rybacy byli bardziej wrażliwi na naukę prawdy niż żydowscy uczeni zapatrzeni w skomplikowane teksty Prawa. Jako pierwsi bez zbędnych pytań poszli za Jezusem, w którym zobaczyli prawdę, a ich prostota umożliwiła przekazanie Jego nauki bez żadnych niepotrzebnych i nieprzedstawiających żadnej rozumowej wartości dodatków ${ }^{64}$.

Teodoret uważa, że w widzialnej naturze tkwi odpowiedź na prawdę bytu, stąd cechą człowieka rozumnego powinno być otwarcie na otaczający świat. Prawda ta jest na tyle silna, że antiocheńczyk porównuje ją do intelektualnego światła, które przenika rzeczywistość. Zamknięcie się na to rozumne światło prawdy powoduje, że mędrzec chodzi w ciemnościach niewiedzy, szukając sposobów wyjścia, jednocześnie za wiarygodne uznając nikłe cienie prawdy w postaci domysłów i przypuszczeń, za którymi podąża ${ }^{65}$. Według Teodoreta istotną kwestią uwiarygadniającą mędrca jest jego pokora, czyli umiejętność porzucania własnych poglądów, kwestionowania i weryfikacji swoich myśli wobec prawdy, którą odkrywa. Tedoret uzasadnia swój pogląd, powołując się na autorytet Sokratesa, który w dialogu z Alkibiadesem wskazywał, czym powinien charakteryzować się mędrzec:

W podobny sposób nakłania też Alkibiadesa, aby się uczył porzuciwszy uprzednio chełpliwe przekonanie o własnej wiedzy: najpierw skarcił go jako człowieka, który nic nie wie, kiedy Alkibiades zapytał: „Czy uważasz, że ja nie mogę odkryć prawdy?”, dorzucił: „Owszem, gdybyś jej szukał”. Kiedy zaś Alkibiades zapytał go ponownie: „Czy sądzisz, żebym nie szukał?”, Sokrates odrzekł: „Oczywiście, ale pod warunkiem, że wiedziałbyś, iż jej nie znasz” ${ }^{\prime 66}$.

64 Theodoretus Cyrrhensis, De fide 37. Por. Theodoretus Cyrrhensis, De materia et mundo 25-30.

65 Theodoretus Cyrrhensis, De principio 1.

66 Theodoretus Cyrrhensis, De fide 84. 
Taka postawa pokory wobec siebie samego i rzeczywistości uwalnia filozofa od pokusy zarozumiałości, pychy i chełpliwości. Oczyszcza jego umysł, tworząc w ten sposób miejsce na nowe treści. Ułatwia także skonfrontowanie się z kolejnymi problemami i tezami innych filozofów. Przykładem takiej postawy jest Platon, który potrafił porzucić wielobóstwo na rzecz uznania istnienia jednego Boga. Jako prawdziwy filozof nie mógł w konfrontacji z prawdą zająć przeciwnego stanowiska. Zaprzeczył całemu swojemu dotychczasowemu myśleniu na rzecz otwarcia się na prawdę - „Przysięgamy z powagą i z pełną wdzięku radosną swobodą, siostrzycą powagi, przysięgamy na władcę bogów teraźniejszych i przeszłych; przysięgamy również na władcę tego i sprawcę Ojca wszechmogącego, którego poznacie, jeśli istotnie będziecie miłośnikami mądrości" ${ }^{67}$. Blask prawdy uwalnia z ciemności niewiedzy i otwiera na dobro samo w sobie, które stworzyło świat i który to świat stanowi odblask jego istoty. Ono także w osobie Jezusa Chrystusa oświeciło świat blaskiem prawdy - Bóg okazał się człowiekowi w widzialnej postaci, by człowiek, który odkrywa to piękno, poruszany wewnętrzną koniecznością, musiał diametralnie zmienić ogląd rzeczywistości, a w konsekwencji przewartościować całe swoje życie.

\section{Wiara jako pelnia poznania}

Dowodem na wyższość chrześcijaństwa (wiary) nad hellenizmem był dla Teodoreta kult męczenników. Porównywał go z kultem wybitnych postaci kultury greckiej, ale tylko i wyłącznie po to, by ukazać, że żaden $\mathrm{z}$ owych bohaterów nie doczekał się czci podobnej tym, którzy porzucili swe życie dla Chrystusa ${ }^{68}$. Ich poświęcenie wynikało z tego, że nie poddali się pokusom ciała, ale oddali je w służbie Bogu i nie zawahali się oddać za swą wiarę życia. Żadna nauka hellenizmu nie doczekała się tak wiernych świadków jej prawdziwości. Dowodem na słuszność wiary są więc osoby, które odkrywszy nauki Chrystusa, były w stanie całkowicie aż po śmierć być im wierne. Jeżeli nie stałaby za nimi prawda, która motywuje człowieka do całkowitego porzucenia dotychczasowych przekonań, na pewno w chwili próby porzuciliby swą wiarę. O sile chrześcijaństwa decydowały także według Teodoreta długofalowe skutki - miejsca kultu męczenników stanowiły zarzewie nowej pobożności. Ich groby odwiedzali wierni, którzy właśnie tam otrzymywali łaski, o które prosili: „Głoszą one

67 Theodoretus Cyrrhensis, De principio 71.

68 Theodoretus Cyrrhensis, De martyribus 60, 69. 
moc spoczywających tam męczenników, a moc ta dowodzi, że ich Bóg jest Bogiem prawdziwym"69. Owocem takiej pobożności byli mnisi, którzy kreowali nowy wzór duchowości i których Teodoret zaliczał do żywych męczenników ${ }^{70}$. Takie przedefiniowanie wydaje się być wyjściem naprzeciw hellenizmowi, dla którego męczeństwo było zupełnie niezrozumiałe, porzucenie ciała dla duchowej kontemplacji Boga natomiast było bliższe ich sposobowi myślenia ${ }^{71}$. Teodoret podjął w ten sposób próbę otwarcia rozumu greckiego na wiarę.

Ideałem filozofa, a zarazem chrześcijańskiego mędrca byli dla Teodoreta mnisi, którzy „wszystkie swoje myśli kierowali na sprawy Boże"72 i potrafili porzucić wszelkie więzy, które krępowały ich umysł (rodzina, ojczyzna, ziemski sposób rozumowania), pragnąc ulecieć ku niebu i oglądać niewidzialne i niewysłowione piękno Boga, Boga prawdziwego $^{73}$. Bóg dla Teodoreta jest właśnie Platońskim dobrem samym w sobie. Jest rozumem, którego istotą jest dobro, którego istotą jest czyste istnienie bez początku i bez końca ${ }^{74}$, ale który nie zamyka się w niewidzialnym świecie, ale ciągle udzielając się, ukazał się w osobie Jezusa Chrystusa, swoim Słowie. Kontemplacja świata powinna prowadzić filozofa do poznania dobra za pomocą wiedzy i prawdy, czyli konsekwentnie do wiary w Boga, a w związku z tym do pełnej akceptacji nauki chrześcijańskiej jako filozofii prawdziwej ${ }^{75}$.

Analiza wypowiedzi wielkich filozofów potwierdza tezy Teodoreta, że każda rzetelna droga mądrości musi doprowadzić do pytania nie tylko o naturę rzeczy widzialnych, ale także niewidzialnych. Zamknięcie się w obrębie zjawisk dostrzegalnych zmysłami może spowodować „błąd bezbożności"76, który przejawia się albo w zarozumiałym zachwycie ogromem posiadanej wiedzy (ubóstwianiem siebie), albo deifikowaniem fenomenów natury. Jeżeli przewodniczką człowieka będzie tylko natura, to może ona według Teodoreta doprowadzić do błędnych, wzajemnie wykluczających się wniosków, czego przykładem są przeczące so-

69 Theodoretus Cyrrhensis, De martyribus 64.

70 Papadogiannakis, Christianity and Hellenism, s. 84-85.

71 Siniossoglou, Plato and Theodoret, s. 125-126.

72 Theodoretus Cyrrhensis, De angelis, et illis qui dii vocantur, ac de malis daemonibus 92.

73 Theodoretus Cyrrhensis, De angelis, et illis qui dii vocantur, ac de malis daemonibus 92.

74 Por. Theodoretus Cyrrhensis, De principio 106-107.

75 Theodoretus Cyrrhensis, De fide 33; Theodoretus Cyrrhensis, De angelis, et illis qui dii vocantur, ac de malis daemonibus 1-21.

76 Theodoretus Cyrrhensis, De fide 121. 
bie opinie filozofów ${ }^{77}$. Rzeczy widzialne powinny prowadzić także do pytania o przyczynę i źródło ich istnienia, a więc o to, co niewidzialne, duchowe. Sam rozum jednak nie jest w stanie zbadać tego świata, gdyż tak jak ,,[...] łatwo może przyjąć, że istnieje coś, co ma przyczynę, coś co zostało zrodzone albo stworzone; nigdy jednak nie uzna istnienia czegokolwiek, co nie ma przyczyny - jeżeli nie otrzyma poręki ze strony

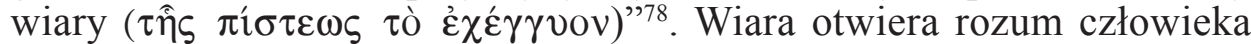
na pełnię rzeczywistości i pozwala badać to, czego sam z siebie umysł bazujący na ludzkim rozumowaniu, nie mógł wywnioskować. Teodoret, począwszy od analizy samego fenomenu wiary w relacjach społecznych, na której opiera się m.in. proces nauczania, działalność specjalistów, bazujących na zaufaniu społecznym, wskazuje na argumenty filozofów, którzy w wierze dostrzegali niezbędny warunek pełnego poznania prawdy: „Arystoteles określił wiarę jako «kryterium» wiedzy, a Epikur nazwał ją antycypacją ( $\pi \rho o ́ \lambda \eta \psi \imath v)$ umysłu ( $\delta \imath \alpha v o i ́ \varsigma \varsigma)$; antycypacja w połaczeniu $\mathrm{z}$ poznaniem $(\gamma \nu \hat{\omega} \sigma \imath \mathrm{v})$ przeradza się $\mathrm{w}$ prawdziwe pojmowanie

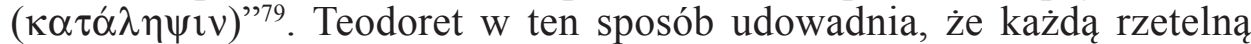
naukę mądrości cechuje otwarcie się na pełnię prawdy o rzeczywistości - świat widzialny i niewidzialny. Rozum jednak nie jest w stanie otworzyć się na świat duchowy, jeżeli nie otrzyma swoistego potwierdzenia ze strony wiary. Ona wyprzedza poznanie, ale bez poznania nie może się zrodzić, gdyż to ona prowokuje kolejne pytania, wzmacnia pragnienie odkrywania, mobilizuje do zagłębienia się w istotę bytu. Wiara dynamizuje umysł, a umysł wypełnia wiarę treścią. Formułując to kryterium, Teodoret odrzuca najważniejszy zarzut, z którym musiało zmierzyć się chrześcijaństwo, czyli wspomniane na początku głoszenie prawd bez żadnych dowodów. Analizując myśli filozofów starożytnych, udowadnia jednak, że równoprawnym elementem poznania rozumowego jest wiara: „Czym oko dla ciała, tym jest wiara dla umysłu - jak oko potrzebuje światła, które odkrywa rzeczy widzialne, tak i umysł potrzebuje wiary, która ukazuje sprawy Boże i strzeże niewzruszonego o nich zdania"

Teodoret wskazuje także na pozorną różnicę między chrześcijańskim a filozoficznym podejściem do rzeczywistości. Filozofia bazuje na oglądzie fenomenów świata, chrześcijaństwo natomiast bazuje na zasłuchaniu

77 Teodoret wymienia i analizuje konkretne poglądy filozofów w każdym kolejnym rozdziale swojego dzieła, tutaj podaję przykładowe tematy: istota Boga (Theodoretus Cyrrhensis, De principio 8-49), istoty duchowe (Theodoretus Cyrrhensis, De angelis, et illis qui dii vocantur, ac de malis daemonibus 54-86).

78 Theodoretus Cyrrhensis, De principio 106-107.

79 Theodoretus Cyrrhensis, De fide 90.

80 Theodoretus Cyrrhensis, De fide 79. 
się w głos samego bytu, czyli Boga i z Niego czerpie swoją wiedzę. Obie drogi prowadzą do tej samej prawdy. Świadectwem tego są dwie osoby. Ze strony filozofii - Platon, który analizując dane pochodzące z natury, używając tylko i wyłącznie logicznego rozumowania, potrafił dostrzec, że natura sama w sobie nie daje odpowiedzi na pytanie o istotę rzeczywistości, ponieważ tego typu próby zawsze kończą się stworzeniem mitologii. Ona jedynie skłania do głębszego poznania, które pociągnięte przez wiarę dostrzega prawdę bytu - Boga, który jest prawdziwym bytem, ponieważ jest wieczny, niezmienny, stały w odróżnieniu od całej widzialnej rzeczywistości, która podlega ciągłym przemianom. On, istniejąc bez początku, jest początkiem wszystkiego i dzięki Niemu wszystko istnieje. Ze strony wiary Mojżesz jest według apologety wzorem poszukiwania prawdy. ,[...] Mojżesz natomiast, który w najwyższym stopniu był człowiekiem Bożym, spisując nauki o Bogu nie poszedł, jak oni, za ludzkim rozumo-

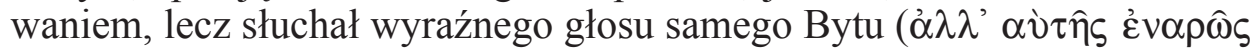

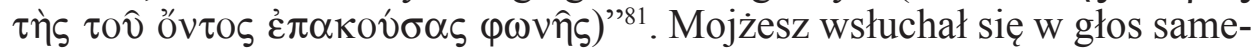
go Boga (filozoficznego bytu samego w sobie), który objawił mu wszystko, co chciał o sobie powiedzieć, a każdy kolejny etap historii zbawienia był odkrywaniem i ubogacaniem tej jednej objawionej prawdy: „Kiedy bowiem Stwórca wszystkich rzeczy nadawał prawa, zaczął je od nakazu czci jedynego Boga; powiedział: «Ja jestem Pan, Bóg twój, który Cię wy-

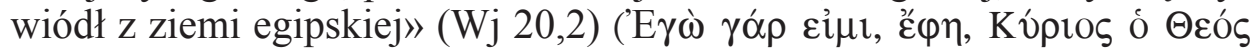

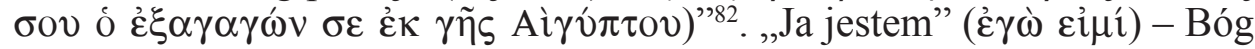
sam przed człowiekiem odkrywa swoją naturę i prawdę rzeczywistości, a jedyne, co pozostaje człowiekowi, to w kontemplacji oddać cześć Bogu i według Jego głosu kształtować swoje życie. Lepiej więc według antiocheńczyka zasłuchać się w głos Boga, niż narazić się na błąd ludzkiego rozumowania, skoro celem obu jest odkrycie tej samej prawdy.

Analiza Teodoreta prowadzi do jednego wniosku: chrześcijaństwo spełnia wszystkie wymagania, które przed rzetelną nauką stawiali filozofowie. Nie zaprzecza racjonalności, ale ją potwierdza i wskazuje odpowiedni kierunek. Chrześcijaństwo więc to prawdziwa filozofia, ponieważ od momentu, kiedy Bóg objawił się Mojżeszowi, głosi jedną i tę samą prawdę, harmonijnie rozwijając ją wobec tego, co Bóg mówi w konkretnych okolicznościach do człowieka wierzącego. Dla Teodoreta oczywiste było, że Platon wyznaczył ścieżkę takiego sposobu myślenia, w którym rozum mógł, wychodząc od odkrywania fenomenu natury świata, bez oporu odkryć Boga, którego dzięki wierze mógł uznać i intelektualnie zgłębiać.

81 Theodoretus Cyrrhensis, De principio 51.

82 Theodoretus Cyrrhensis, De principio 51. 
Tę istniejącą odwiecznie, bez początku istność biskup Cyru nazywa

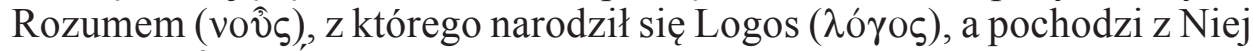
Duch $(\pi v \varepsilon \hat{\jmath} \mu \alpha)$ Swięty. Najwyższą prawdą, do której dążyli filozofowie greccy, jest właśnie Trójjedyny Bóg. Człowiek natomiast może odkrywać tę prawdę dzięki temu, że posiada umysł (voûs), który jest ikoną Boga w człowieku stworzonym na Jego obraz i podobieństwo oraz zdolnym do logicznego rozumowania. Duch prowadzi i pobudza ducha każdego człowieka ku odkryciu jedynego Boga i oddaniu się Jego kontemplacji ${ }^{83}$. Nawiązując do interpretacji myśli Platona przez Plotyna i Numeniosa, Teodoret wskazuje, że w ich interpretacji, a byli oni klasycznie wykształconymi filozofami greckimi, Bóg Ojciec jest najwyższym dobrem, dobrem samym w sobie. Rozumem jest Syn i Logos, wszechożywiającą duszą natomiast jest Duch Święty ${ }^{84}$. Człowiek więc obdarzony duszą

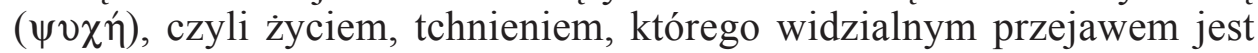
jego umysł zdolny do logicznego rozumowania, jest naturalnym odbiciem owej prawdy rzeczywistości. Dusza człowieka może zwrócić się poprzez ciało w kierunku zmysłowości i nigdy niezaspokojonych pragnień albo poprzez umysł pokonać uczucia, wznieść się ponad ziemskie przyjemności ku kontemplacji najwyższego dobra, którym jest dobro samo w sobie - Bóg. Jedynie rozum według apologety ze swej struktury jest zdolny do kontemplacji spraw umysłowych (duchowych) i tylko on prowadzi duszę ku prawdzie rzeczywistości. Tak skonstruowana definicja prawdziwego filozofa odkrywa przed myślą grecką chrześcijaństwo jako punkt kulminacyjny wszelkich poszukiwań mądrości. Prawdziwym chrześcijaninem, a więc prawdziwym filozofem w ujęciu Teodoreta jest mnich, który nie tylko potrafił skupić się na poszukiwaniu prawdy o rzeczywistości, odrzucając wszelkie inne dobra, ale obdarzony wiarą potrafił swój umysł wznieść ku kontemplacji dobra samego w sobie, które stanowiło i od którego pochodziła Prawda rzeczywistości. Wiara była więc elementem, który pozwalał umysłowi wznieść się ku Bogu. Ona była elementem, którego brakowało filozofom, a która dzięki Chrystusowi, prawdziwemu Słowu Boga, Słowu samego Bytu, stała się widzialna i osiągalna dla człowieka.

Pełno jest takich ludzi w miastach, w wioskach, na szczytach gór i wąwozach. Jedni mieszkają we wspólnotach i kształtują w duszach swoich pomniki filozofii; inni pędzą życie po dwóch czy trzech; jeszcze inni zamykają się w odosobnieniu i nie pozwalają oczom swoim cieszyć się pięknem rzeczy widzialnych, a wolny czas przeznaczają na to, aby dusza

\footnotetext{
83 Theodoretus Cyrrhensis, De principio 107.

84 Theodoretus Cyrrhensis, De principio 84-86.
} 
(v⿳亠丷) rozkoszowała się kontemplacją spraw umysłowych ( $\tau \hat{\eta} \Theta \varepsilon \omega \rho i ́ \alpha \tau \hat{\omega} v$ $\operatorname{vo\eta } \tau \hat{\omega} \nu)^{85}$.

Mnisi realizowali w rzeczywistości Platoński ideał umierania dla świata i upodobnienia się do Boga. Wzorem takiego ascetycznego życia byli dla Teodoreta z jednej strony asceci syryjscy, których charakteryzował radykalizm w stosunku do swojego ciała, z drugiej strony męczennicy, którzy w sposób skrajnie dotykalny ukazywali poświęcenie swojego cielesnego życia dla Chrystusa w wolnym wyborze śmierci męczeńskiej ${ }^{86}$. Ciało stało się więc narzędziem dla osiągnięcia doskonałej filozofii polegającej na transcendencji od ludzkiej natury, by umysł mógł wznieść się ku kontemplacji Boga i upodobnienia się do Niego ${ }^{87}$. Taka postawa wymagała jednak całkowitego odseparowania się od doczesnego świata, by wyzwolić umysł z wszelkich pokus ciała. Syryjska asceza, którą Teodoret w dokładny sposób opisuje w Historii Bożej Miłości na przykładzie konkretnych mnichów, stanowiła dla niego wzór duchowości. Cechowała się jednak ona bardzo radykalnym, wręcz ekstremalnym traktowaniem swojego ciała i doczesności. Jak wskazuje E. Wipszycka

W kręgach ascetycznych panowało przekonanie iż asceta, godny tego wielkiego imienia, zbliża się do stanu rajskiego bytowania, takiego, jaki był dany Adamowi i Ewie, którzy nie potrzebowali okrycia, ognia do przygotowywania potraw, ochrony przed dzikimi zwierzętami i którzy pędzili w raju żywot, mający na celu adorację Boga. Asceta wypełniający dosłownie wzory biblijne stawał się w tej perspektywie częścią świata już zbawionego, nieobciążonego grzechem pierworodnym ${ }^{88}$.

W środowisku syryjskim ciało i jego potrzeby musiały zostać powstrzymane, by nie hamowały duszy w jej nadprzyrodzonym oglądzie Boga. Według jego przedstawicieli nie mogło to zostać osiągnięte bez ogromnych cierpień fizycznych i psychicznych, bez walki, która niekiedy przeradzała się w samoudręczenie ciała. Asceta syryjski stawał sam w obliczu pokus, by w skrajnej samotności i indywidualnej walce stanąć sam na sam z prawdziwym Bogiem. Celem owego radykalizmu było dosłow-

85 Theodoretus Cyrrhensis, De angelis, et illis qui dii vocantur, ac de malis daemonibus 93.

${ }^{86}$ Teodoret poświęca cała jedną mowę obronie męczenników - De martyribus.

87 Papadogiannakis, Christianity and Hellenism, s. 99

88 E. Wipszycka, Charakter i formy ascetyzmu syryjskiego, w: Teodoret z Cyru, Dzieje Miłości Bożej. Historia mnichów syryjskich, tł. K. Augustyniak, ŹM 7, Kraków 2011, 27. 
ne uśmiercenie swojego ciała, by nie przeszkadzało ono w kontemplacji Boga. W ten sposób określenie mnicha jako męczennika nabierało wymiaru rzeczywistej ofiary ze swojego ciała aż po ekstremalne jego ograniczenie $^{89}$. To, co było dla filozofii jedynie intelektualnym ćwiczeniem, stało się w praktykach ascetycznych Syrii rzeczywistością. Mnich w Leczeniu jest według Teodoreta spełnieniem Platońskiego ideału, który zaprezentował w Teajtecie, a którego żaden z najwybitniejszych przedstawicieli myśli greckiej nigdy nie osiągną ${ }^{90}$. W tym kontekście Teodoret przytacza przykład Sokratesa, którego życie nie odpowiadało wyznaczonym standardom filozoficznego życia:

W tym miejscu Platon odmalował sposób postępowania naszych filozofów, bo wśród Greków nie było nikogo takiego. Sokrates na przykład, koryfeusz filozofów, spędzał czas na dysputach w gimnazjonach i warsztatach rzemieślniczych; już to przebywał w mieście, już to schodził do Pireusu, żeby oglądać uroczyste procesje; wcielony do oddziału hoplitów walczył pod Potydają i pod Delionem, a kiedy przyszedł na wspólny posiłek, znosić musiał kpiny Arystofanesa i zaczepki Alkibiadesa: opowiada o tym Uczta Platona; uczęszczał też do teatru, aby wraz z ludem przypatrywać się przedstawieniom. A zatem słowa Platona w żadnym najmniejszym stopniu nie odnoszą się do niego [...]. Ci zaś, którzy umiłowali filozofię ewangeliczną, z daleka trzymają się od miejskich hałasów: osiadłszy na górskich szczytach, albo znajdując upodobanie w życiu na pustyni, poświęcili się kontemplacji spraw boskich i życiu, które do tej kontemplacji pasuje ${ }^{91}$.

Wyższość chrześcijaństwa nad hellenizmem tkwiła przede wszystkim $\mathrm{w}$ praktykowaniu cnoty, a nie tylko w kulturalnej przynależności. Wiara w Chrystusa to nie tylko deklaracja, ale droga życia, która wprost odpowiada prawdziwej filozofii, która miała łączyć w sobie elementy intelektualne z egzystencjalnymi ${ }^{92}$.

Mnich według Teodoreta jest wzorem doskonałego chrześcijanina. Uniwersalnym typem człowieka doskonałego, którego postawa nie może być tylko i wyłącznie przedmiotem czci, ale powinna motywować do zmiany swojego życia i ustawienia we właściwej kolejności hierar-

89 E. Wipszycka w swoim artykule analizuje przyczyny powstania takiej formy radykalizmu oraz przedstawia okoliczności geograficzne, które to umożliwiały: Wipszycka, Charakter i formy, s. 9-36.

90 Siniossoglou, Plato and Theodoret, s. 125-128.

91 Theodoretus Cyrrhensis, De virtute activa 26-27.

92 Papadogiannakis, Christianity and Hellenism, s. 103. 
chii wartości. Jego droga życia ukazuje według cyreńczyka właściwy kierunek chrześcijańskiego postępowania. Powinno być ono otwarte ku kontemplacji Boga, samego dobra i według Niego kształtowane. Tak rozumiana mądrość, wynikająca z praw Ewangelii, przestaje być własnością elit, ale przenika wszelkie stany i kultury, by pokonać rozdział pomiędzy grecko-rzymską i helleńsko-barbarzyńską kulturą. Chrześcijaństwo w ten sposób staje się praktyczną, uniwersalną filozofią bazującą na przekonaniu o jedności natury ludzkiej i uniwersalizmu Chrystusowego zbawienia ${ }^{93}$. Dzięki Chrystusowi każdy może osiągnąć zbawienie, moralną doskonałość, jedynym warunkiem jest skierowanie umysłu na Boga i podporządkowanie temu oglądowi całego swojego życia oraz postępowania.

Elementem, który wyróżnia apologię Teodoreta, jest ideał mnicha (w formie ascetyzmu syryjskiego) jako prawdziwego filozofa. W ten sposób próbuje on dotrzeć do wykształconych obywateli Cesarstwa i przekonać ich, że chrześcijaństwo jest naturalną kontynuacją helleńskich ideałów. Prosta nauka Chrystusa pokazana jest jako najwyższa filozofia, która powinna kształtować nowe społeczeństwo. Teodoret otwiera w ten sposób grecki rozum na wiarę i udowadnia ich komplementarność. Stanowiło to fundament pod budowę chrześcijańskiej „,paidei”, chrześcijańskiego hellenizmu i pozwoliło na pełne schrystianizowanie Cesarstwa. Mnich stał się ideałem filozofa, chrześcijanina i człowieka jako żywy męczennik poświęcający swe doczesne życie wierze w Boga.

Teodoret z Cyru stał się łącznikiem pomiędzy filozofią grecką a chrześcijaństwem. Ukazał nie tylko racjonalność wiary w Chrystusa, ale zarazem wskazał, że jest ona najbardziej zgodną z rozumem drogą, po której każdy mędrzec powinien kroczyć. Dla Teodoreta Chrystus sprawił, że ludzka natura na powrót stała się ,rozsądna i stateczna" 94 . Filozofowie greccy poruszali się więc na drogach mądrości, krocząc jakby we mgle, mając, tak jak określa to Teodoret, za przewodniczkę tylko naturę. Bóg objawiał im przez rzeczy stworzone prawdę o rzeczywistości, ale jednak byli zdani tylko na siebie, dzięki chrześcijaństwu powinni jednak dostrzec „blask rozumnej światłości”"95, tkwiący w naturze, którym jest wiara w Boga - dobro samo w sobie i prawda, wokół której należy kształtować całe swoje życie.

93 Por. Papadogiannakis, Christianity and Hellenism, s. 112-117.

94 Theodoretus Cyrrhensis, De angelis, et illis qui dii vocantur, ac de malis daemonibus 86.

95 Theodoretus Cyrrhensis, De principio 1. 


\title{
5. Podsumowanie
}

Prawdziwą drogą rozumnego człowieka powinno być chrześcijaństwo jako najwyższa filozofia. Ta zapomniana koncepcja Teodoreta mogłaby stać się nowym otwarciem w dialogu ze współczesnym człowiekiem tak bardzo ubóstwiajacym dokonania rozumu. Metoda postępowania antiocheńczyka daleka jest od potępiającego czy oskarżycielskiego tonu. Krok po kroku, wychodząc od najprostszych doświadczeń oraz posługując się autorytetami spoza chrześcijaństwa, uzasadnia rozumną konstrukcję wiary i jej niezbędność w pełnym i kompletnym procesie poznawczym. Doktryny relatywizmu i modernizmu popularne we współczesności albo zupełnie odrzucają kwestię istnienia Boga albo ubóstwiają go, przeradzając się w jakąś nową formę fideizmu, a nawet politeizmu. Koncepcja Teodoreta i jego sposób podejścia powinien stać się inspiracją dla współczesnych chrześcijan, w jaki sposób rozmawiać $\mathrm{z}$ ateistami czy antyteistami, a także z teistami (nowe ruchy religijne), by doprowadzić ich do odkrycia pełni rozumnej prawdy, która tkwi w chrześcijaństwie.

\section{Rozum jako naturalna droga do wiary - zapomniana koncepcja Teodoreta z Cyru}

(streszczenie)

\begin{abstract}
Artykuł skupia się na mało znanym w środowisku polskim syryjskim Ojcu Kościoła Teodorecie z Cyru, który w swoim dziele Leczenie chorób hellenizmu stworzył oryginalną metodę apologetyczną. Polegała ona na przedstawieniu rozumu, racjonalnego myślenia jako naturalnej drogi do wiary, by w ten sposób przekonać do chrześcijaństwa wykształconych przedstawicieli kultury greckiej. Posiadając zarówno klasyczne greckie wykształcenie, jak i doświadczenie życia mniszego w syryjskiej formie ascezy, potrafił połączyć obie te rzeczywistości, wskazując na chrześcijaństwo jako prawdziwą filozofię (pełnię poznania) oraz na mnicha jako ideał filozofa. Główną metodą Teodoreta jest uzasadnienie racjonalności chrześcijaństwa polegajace na stworzeniu kryteriów rozumności nauki zgodnie z myślą i poglądami uznanych w kulturze greckiej autorytetów. Metoda ta mogłaby stać się podstawą pod wspólne dla wszystkich chrześcijan działanie, by współczesny racjonalny świat ponownie otworzył się na pełnię prawdy bytu - Jezusa Chrystusa.
\end{abstract}

Słowa kluczowe: Teodoret z Cyru; duchowość syryjska; wiara; rozum; prawda

\section{Reason as a Natural Way to Faith - Forgotten Concept of Theodoret of Cyrus}

\author{
(summary)
}

The article focuses on the Theodoret of Cyrus, a little known in the Polish Patrology Syrian Church's Father, who in his book "Healing Hellenic Diseases" created an origi- 
nal apologetic method. It consisted in the presentation of reason - rational thinking as a natural way to faith, in order to convince the educated representatives of Greek culture to Christianity. Theodoret, who had classical Greek education and experience of strict monastic life in the Syrian form of asceticism was able to combine both of these realities to indicate Christianity as a true philosophy (fullness of knowledge) and the monk as the ideal of a philosopher. The main method of Theodoret was to evidence the rationality of Christianity by creating demands for the rationality of science. He made this by alluding to the thoughts and opinions of the authorities recognized in Greek culture. In modern time this method could become the way to convince all rational world to accept the Christian teaching and consequently to open to the fullness of the truth of being - Jesus Christ.

Keywords: Theodoret of Cyrus; Syrian spirituality; faith; reason; truth

\section{Bibliografia}

\section{Źródla}

Theodoretus Cyrrhensis, Historia Religiosa, PG 82, 1283-1496, tł. K. Augustyniak: Teodoret z Cyru, Dzieje miłości Bożej. Historia mnichów syryjskich, ŹM 7, Kraków 1994.

Theodoret, Interpretatio in quattuordecim epistulas S. Pauli, PG 82 225-460, tł. S. Kalinkowski: Teodoret z Cyru, Komentarz do Listów Św. Pawła do Rzymian, ŹMT 5, Kraków 1997, 21-131; Teodoret z Cyru, Komentarz do 1 i 2 Listu do Koryntian, ŹMT 9, Kraków 1998, 19-167; Teodoret z Cyru, Komentarz do Listów Św. Pawła do: Galatów, Efezjan, Filipian, Kolosan, ŹMT 14, Kraków 1999, 25-125; Teodoret z Cyru, Komentarz do Listów Pawłowych do Tesaloniczan, Tymoteusza, Tytusa, Filemona i Hebrajczyków, ŹMT 20, Kraków 2001, 101-275.

Theodoretus Cyrrhensis, Graecarum affectionum curatio, PG 83, 783-1152, t1. S. Kalinkowski: Teodoret z Cyru, Leczenie chorób hellenizmu, Warszawa 1981.

Theodoretus Cyrrhensis, Haereticarum fabularum compendium, PG 80, 336-553, tł. P.M.

Szewczyk: Teodoret z Cyru, O herezjach, ŹMT 77, Kraków 2016.

Theodoretus Cyrrhensis, Reprehensio XII capitum, PG 76, 385-452.

\section{Opracowania}

Augustyniak K., Historia mnichów syryjskich, w: Teodoret biskup Cyru, Dzieje miłości Bożej. Historia mnichów syryjskich, ŹM 7, Kraków 1994, 37-53.

Azéma Y., Théodoret, „Dictionnaire de spiritualité”, t. 15, 418-435.

Blomfield J., Prolegomena, w: Nicene and Post-Nicene Fathers. Second Series, vol. 3, red. P. Schaff - H. Wace, Edinburgh 1996, 1-23.

Brock S., Early Syrian Ascetism, „Numen” 20 (1973) 1-19.

Brock S., Greek and Syriac in Late Antigue Syria, w: Literacy and Power in the Ancient World, red. A.K. Bowman - G. Woolf, Cambridge 1994, 149-160. 
Cameron A., The Last Pagans of Rome, New York 2011.

Canivet P., Le monachisme syrien selon Théodoret de Cyr, Paris 1977.

Canivet P., Théodoret et le monachisme syrien avant le concile de Chalcédoine, Paris 1961.

Dobosz W., Teodoret z Cyru - niedoceniany teolog z Vw., „Przegląd Piśmiennictwa Teologicznego" 22 (2016) nr 1, 5-44.

Drączkowski F., Wychowawcza funkcja Prawa Starego Testamentu w koncepcji Klemensa Aleksandryjskiego, RTK 26 (1979) z. 3, 17-29.

Escolan Ph., Monachisme et Église. Le monachisme syrien du IVe au VIIe siècle: un monachisme charismatique, Paris 1999.

Fiedorowicz M., Teologia Ojców Kościoła. Podstawy wczesnochrześcijańskiej refleksji nad wiara, Kraków 2009.

Gaşpar Ch., An oriental in Greek dress: the making of a perfect christian philosopher in the «Philothetos Historia» of Theodoret of Cyrrhus”, „Annual Medieval Studies” 14 (2008) 193-229.

Gaşpar Ch., Theodoret of Cyrrhus and the Glory of the Syrian Ascetics: Epic terminology in Hagiographic Contexts, „Archaeus: Etudes d'Histoire des Religions” 4 (2000) z. 1-2, 211-240; z. 4, 151-178.

Harvey S.A., The sense of Stylite. Perspectives on Simon the Elder, VigChr 42 (1988) 376-394.

Hunt E.J., Christianity in the Second Century, Routledge, London - New York 2003.

Jaeger W., Wczesne chrześcijaństwo i grecka paideia, tł. K. Bielawski, Bydgoszcz 2002.

Jan Paweł II, Fides et ratio, Watykan 1998.

Kalinkowski S., Wstęp, w: Teodoret z Cyru, Leczenie chorób hellenizmu, tł. S. Kalinkowski, Warszawa 1981, 5-15.

Karamanolis G., The Philosophy of Early Christianity, Acumen 2013.

Karaś M., Apologetyka Teodoreta z Cyru wobec filozofii Platona, „Kwartalnik filozoficzny" 23 (2003) z. 3, 33-60.

Kelly J.N.D., Początki doktryny chrześcijańskiej, tł. E. Stanula, Warszawa 1988.

Leonkiewicz Ł., Wybrani Ojcowie Kościoła wobec filozofii starożytnej (cz. II), „Elpis” 16 (2014) 76-81.

Leszczyński R.M., Starożytna koncepcja Logosu i jej wpływ na myśl wczesnego chrześcijaństwa, Warszawa 2003.

Longosz S., Wstęp, w: Św. Bazyli Wielki, Do młodzieńców o pożytkach z czytania książek pogańskich, VoxP 32 (2012) t. 57, 895-904.

McCullough W.S., A Short History of Syriac Christianity to the Rise of of Islam, Chico 1982.

Millar F., Theodoret of Cyrrhus: a Syrian in Greek Dress?, w: From Rome to Constantinople: Studies in Honour of Averil Cameron, red. H. Amirav - R.B. ter Haar Romeny, Leuven 2007, 105-125.

Misiarczyk L., Wstęp. Apologetyka wczesnochrześcijańska, w: Pierwsi Apologeci Greccy, BOK 24, Kraków 2004, 5-91. 
Pałucki J., Chrystus Boski Lekarz w Pismach Klemensa Aleksandryjskiego, w: Wczesnochrześcijańska asceza. Zagadnienia wybrane, red. F. Drączkowski - J. Pałucki, Lublin 1993, 15-34.

Papadogiannakis Y., Christianity and Hellenism in the fifth-century Greek East. Thedoret's apologetics against the greeks in context, Cambridge - London 2012.

Pásztori-Kupán I., Theodoret of Cyrus, London - New York 2006.

Pawłowski K., Spotkanie starożytnego chrześcijaństwa z filozofia grecka w czasach Justyna Męczennika i Klemensa Aleksandryjskiego, CT 86 (2016) 69-84.

Perchai R.J., Antiochene Theoria in the Writings of Theodore of Mopsuestia and Theodoret of Cyrus, Augsburg 2015.

Pouderon B., Les apologetics chrétiens et la culture greque, Paris 1998.

Price R., The Three Chapters Controversy and Council of Chalcedon, w: The Crisis of the Oikoumene: The Three Chapters and the Failed Quest for Unity in the Sixth-Century Mediterranean, red. C. Chazelle-C. Cubit, Turnhout 2007, 17-37.

Quasten J., Patrology vol. 3 The Golden Age of Greek Patristic Literature: From the Council of Nicea to the Council of Chalcedon, Westminster 1992.

Rousseau P., Late Roman Christianities, w: The Cambridge History of Christianity, t. 3, red. T.F.X. Noble - J.M.H. Smith, Cambridge 2008, 21-45.

Rousseau P., Moses, monks, and mountains in Theodoret's «Historia religiosa», w: Il monachesimo tra Eredità e Aperture, red. M. Bielawski - D. Hombergen, Rome 2004, 323-346.

Schor A.M., Theodoret's People: Social Networks and Religious Conflict in Late Roman Syria, Berkeley - London 2011.

Siniossoglou N., Plato and Theodoret: the Christian appropriation of Platonic philosophy and the Hellenic intellectual resistance, Cambridge 2008.

Skotnicka K., Rola modlitwy w życiu syryjskich mnichów wedlug Teodoreta z Cyru, VoxP 34 (2014) t. 65, 471-492.

Szczerba W., Tradycja filozoficzna a Biblia w Kościele pierwszych wieków. Casus Grzegorza z Nyssy, „Theologica Vratislaviensia” 2 (2007) 137-146.

Taylor D., Bilingualism and Diglossia in Late Antique Mesopotamia, w: Bilingualism in Ancient Society: Language Contact and the Written Word, red. J.N. Adams, Oxford 2002, 298-331.

Ulrich J., The Reception of Greek Christian Apologetics in Theodoretus" "Graecarum affectionum curatio», w: Continuity and Discontinuity in Early Christian Apologetics, red. J. Ulrich - A.C. Jacobsen - M. Kahlos, Frankfurt am Main - Oxford 2009, 113-130.

Urbainczyk T., Theodoret of Cyrrhus. The Bishop and the Holy Man, Ann Arbor 2002.

Vööbus A., History of Ascetism in the Syrien Orient. A Contribution to the History and Culture in the near East, Louvain 1960.

Widok N., Koncepcja eklektyzmu Klemensa Aleksandryjskiego, STHŚO 14 (1993) 25-37.

Wipszycka E., Charakter i formy ascetyzmu syryjskiego w: Teodoret z Cyru, Dzieje Miłości Bożej. Historia mnichów syryjskich, tł. K. Augustyniak, ŹM 7, Kraków 2011, 9-36. 
Wipszycka-Bravo E., Wierni u stóp Symeona Stupnika. O społecznej funkcji ascetyzmu syryjskiego, RTK 26 (1979) z. 4, 91-117.

Wróblewska J.E., Św. Justyn, ,, Sprawiedliwy pośród narodów”, VoxP 32 (2012) t. 57, 751-754.

Zakrzewski G.J., Filozofia antyczna w pierwotnym chrześcijaństwie, Lublin 2013.

Zgraja B., Chrystus Boski Logos - wzór i mistrz cnoty wedtug Klemensa Aleksandryjskiego, SW 47 (2010) 49-69. 